\title{
Impact of ICT Adoption on Students Learning
}

\author{
Dr. Lalitha. B.S 1 $^{*}$
}

${ }^{1}$ Assistant Professor, PG Department Of Commerce Sivanand Sarma Memorial RV College, Bangalore, India

DOI: $\underline{10.36348 / \text { jaep.2021.v05i04.001 }}$

| Received: 06.03.2021 | Accepted: 27.03.2021 | Published: 02.04.2021

*Corresponding author: Dr. Lalitha. B.S

\section{Abstract}

Technology has occupied a prominent position across the globe. It has come in to stay but with its own advantages and disadvantages. For many ICT (Information and Communication Technology) has done more harm than good, particularly amongst the youth. This study investigates the adoption of information and communication technology and its impact on the student's academic performance. Factors like availability, accessibility and user ability of ICT in students of Bangalore Central University selected affiliated colleges have been checked along with their academic performance. To verify the hypothesis, Pearson correlation analysis method has been used to find out whether students learning have an effect from ICT. The findings revealed that the ICT resources are inadequate to use in these colleges. The number of computer functional units is limited, and so the accessibility to these resources is also restricted. From the study it was mainly understood that only some of the basic concepts and curriculum based programs were only taught to a minimum extent. In depth learning for usage of ICT was not in practice. From the research it was found that availability, accessibility and user ability has significant impact on the students learning.

Key words: ICT, Education, Availability, accessibility, user ability, student learning.

Copyright () 2021 The Author(s): This is an open-access article distributed under the terms of the Creative Commons Attribution 4.0 International License (CC BY-NC 4.0) which permits unrestricted use, distribution, and reproduction in any medium for non-commercial use provided the original author and source are credited.

\section{INTRODUCTION}

Education is the process of facilitating learning or the acquisition of knowledge, skills, beliefs and habits. Education frequently takes place under the guidance of educators, but the learners educate themselves. Education in the narrow and common-sense usage is what takes place during the process of teaching in the educational institutions. In this era of globalization and technological evolution, education is considered as a first, prominent step for every human activity. Guided by the National Policy on ICT in school education, the education curriculum has been designed to create wider horizons for students and keep them informed of their career pursuits. The prevalence and rapid development of information and communication technologies has transformed human society from the information technology age to the knowledge age.

Information and Communication technology are defined as all devices tools, content, resources, forums, and services, digital and those that can be converted into digital forums, which can be deployed for realizing the goals of teaching learning, enhancing access to and reach of resources, building of capacities, as well as management of the educational system. This will not only include hardware devices connected to computers, and software applications, but also interactive digital content, radio and television services, web-based content repositories, interactive forums, learning management systems, and management information systems. These will also include process for digitization and management of content, development of platforms and processes for capacity development and creation of forums for interaction and exchange. Information and Communication technology (ICT) has become an important source of innovation and improvement of efficiency for many sectors across the globe. ICTs are generally accepted as a modern instrument tool that enables the educators to modify the teaching methods; they use in order to increase the student's interest.

Information and communication are integral to human society. The $21^{\text {st }}$ century has seen ICT use becoming an inevitable part of life. The emergence and advancement of ICTs have changed the way of teaching and learning process is being conducted. The importance of ICT cannot be underestimated when MHRD (Ministry of Human Resource Development) considered ICT as the future tool for higher education in India. ICT has become a major source of innovation. This has led to the development and efficiency of many sectors across the globe. In the education sector, 
Lalitha. B.S., J Adv Educ Philos, Apr, 2021; 5(4): 90-97

application of ICT has become a critical part of the learning process for both inside and outside the classroom setting. Educators can now use ICT as a tool that allows transformation in the instructional approach in the classroom setting to get better performance [1]. The Indian Government, the universities, management and researchers have invested several crores of rupees to adopt ICT in the education sector during the last two decades.

The MHRD is completely vested with the overall development of basic infrastructure for Higher Education. Under this development programme, the MHRD looks after expansion of access and qualitative improvement in higher education through World Class Universities, colleges and other institutions through adoption of various Digital Initiatives in Higher Education. But the expansion of such facilities is limited through the infrastructure and human resource limitations. These limitations can be used to enhance the accessibility and quality of learning. With a long term objective of providing quality education using ICT and expanding the learning horizons the National Mission on Education through ICT (NMEICT) was launched. Several IT interventions have been achieved in the past 5 years and have definitely the potential to change the higher education scenario. Some of the prominent ones are SWAYAM, SWAYAM prabha, National Digital Library, e-Shodh Sindhu .etc

Most universities/colleges that have adopted ICT completely have witnessed immense development in terms of improvement in learning methods, teaching, research and development. But the impact of ICT on the performance and achievement of students are yet to be established. ICT adoption in this study is a gradual shift to automation of the educational process not only in terms of student's admission, registration and evaluation but also in terms of developing a customized learning management system (LMS) with transfer of courses and all related data to it. Previously only the blackboard was used to teach the students. Now the faculty members as well as the students are allowed to access to the LMS along with its all services and the specialized online learning tools. The adoption of such steps has facilitated the educational process to a greater extent.

\section{Conceptual Framework}

Accessibility of ICT in India is defined as availability of IT in college/university, availability of high speed internet for IT labs, personal devices via Wi$\mathrm{Fi}$, availability of online media via $24 / 7$ access within the institution premises or outside the premises via smartphone apps [2].

Usage of ICT in India can be defined as the usage of recent innovations in ICT in college/university, usage of ICT /gadgets instead of the traditional chalk and board concept, usage of web matter for completion of assignments, usage of video conferencing for live classes, monitoring of classes of teachers and students, recording the attendance of students. ( Debarun Chakraborty et al. [2]. It also refers to the usage of these resources for achievement of specified goals.

Albert Einstein in one of his quotes said "Once you stop learning you start dying". Learning is a natural phenomenon and is natural to all organisms including both humans and animals. According to Woodworth. "The process of acquiring new knowledge and new responses is the process of learning."

\section{LITERATURE REVIEW}

Debarun Chakraborty et al. 2018 [2] in their article "Effectiveness of ICT in strengthening the process of Higher education system in India" have analyzed that ICT has a great influence on higher education system in India. India is also under the process of invigorating ICT for advanced education framework in this country. The researcher has checked the effective implementation of ICT from availability, usage, knowledge and cost. Wael Sh.Basri. et al. [6, 7]“. ICT adoption impact on students' academic performance : Evidence from Saudi universities" in their article have observed the adoption of information technology and its impact on the student's academic performance The effect of gender, GPA and students taking up ICT as a major subject has been studied with a sample size of 1000 students. The findings revealed that ICT adoption has an impact on academic performance in a conservative environment. Nzwili. K. Mwendwa in the article [5]". Availability of Resource Materials and Facilities for ICT Integration in the Public Primary School Curriculum in Kitui County, Kenya" revealed that even though most schools have electricity connections still they did not possess ICT facilities like desktops, whiteboards, CD-ROMs, and antivirus. In some of the schools even though laptops were available it was mainly used for storing records, examinations questions, teacher plans.etc. Majority of the schools did not have internet connectivity to have integration with the curriculum. Mohd.T.Al-Hariri and Abdulghani. A Al-Hattami in their article [4]". Impact of students use of technology on their learning achievements in physiological courses at the University of Dammam" have analyzed that people learn considerably better with both images as well as words rather than words alone. The findings revealed that there must be a combination of smart devices to handheld devices like laptops, mobiles which have immediate access to the e-facility of the University to classroom learning.

\section{Aim of the study}

This study is based on the data collected from Bangalore Central University affiliated colleges. The rationale behind choosing this university is to identify 
Lalitha. B.S., J Adv Educ Philos, Apr, 2021; 5(4): 90-97

the perceived effect of the availability, accessibility and user ability of ICT resources on student learning

\section{METHODS}

\section{Statement of the Problem}

Students learning have occupied a prominent position in any academic achievement debate. ICT opens the plethora of opportunities for educational institutions to support, harness and use technology to complement the teaching and learning process. Even though the university students have advocated the usage of ICT resources, yet the University still faces the challenge of transformation of the students learning process to provide students with the skills to function effectively in this competitive and challenging environment. Unless this problem is addressed the amount of investment in IT will go for a waste and the teaching becomes lethargic. The University will fail to achieve the objective of producing industry ready students which is completely dependent on ICT. In view of this there is a need to study the availability, accessibility and user ability of ICT of students learning in colleges affiliated to Bangalore Central University

\section{OBJECTIVES OF THE STUDY}

- To determine the impact between availability of ICT resources on the students learning
- To determine the impact between accessibility of ICT resources on the students learning

- To determine the impact between user-ability of ICT resources on the students learning

\section{Hypothesis of the study}

1. Availability of ICT has effect on student learning in colleges affiliated to Bangalore Central University

2. Accessibility of ICT has effect on student learning in colleges affiliated to Bangalore Central University

3. User-ability of ICT has effect on student learning in colleges affiliated to Bangalore Central University

\section{Scope of the Study}

The study on impact of ICT adoption was carried out in Bangalore Central University affiliated colleges during December 2019 to January 2020. The study was conducted particularly to determine the effects of availability, accessibility and user ability of ICT resources on students learning in colleges affiliated to Bangalore Central University+

\section{RESEARCH MODEL}

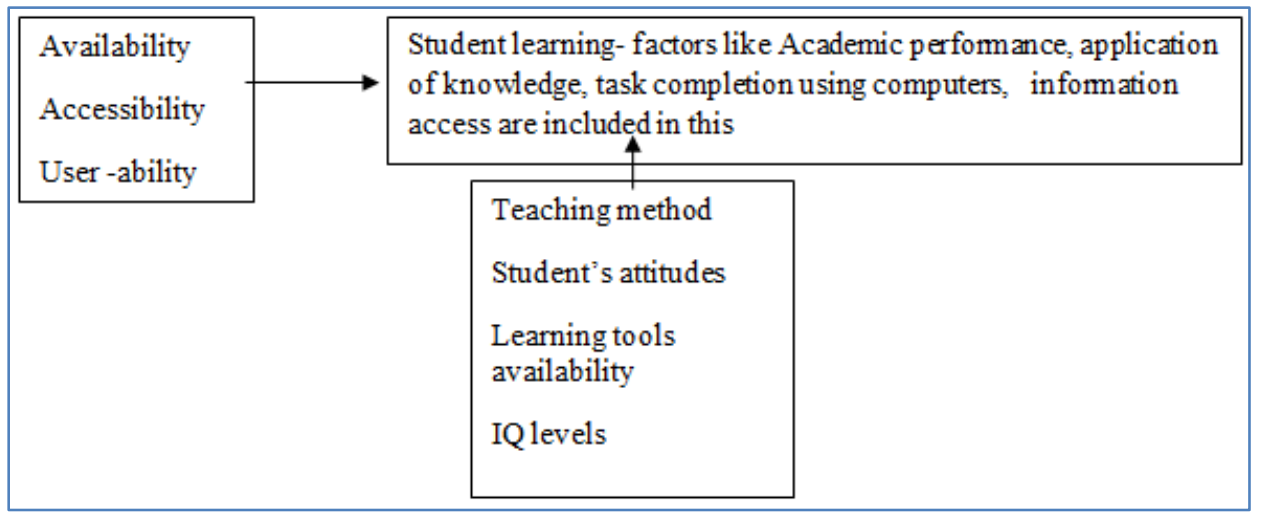

Source: Spiro. et al. [3]

Independent variables- Availability, Accessibility, User-ability

Dependent Variable- Students learning and associated factors

\section{Data collection tools and techniques}

Since the student population is huge, sampling was used to study a representative of the total population. Stratified and convenient sampling was adopted for the study. The researcher identified students, faculty members and administrators as the relevant stratum and their actual representation of the population. Students formed the major target of the study, while faculty members and administrators were taken up through convenient sampling. Primary Data was collected from a predesigned questionnaire while secondary data was collected from official records, newspaper accounts, reports, literature review. etc. To establish validity of the questionnaire, it was subjected to scrutiny and pretest before the actual survey.

Table-4.1: Table showing the questionnaire return rate

\begin{tabular}{|l|l|l|l|}
\hline Categories & Sample & Questionnaires returned & Percentage \\
\hline Students & 250 & 165 & $66 \%$ \\
\hline Faculty Members & 16 & 10 & $62.5 \%$ \\
\hline
\end{tabular}


Lalitha. B.S., J Adv Educ Philos, Apr, 2021; 5(4): 90-97

From the above table it can be observed out of the total 250 questionnaires distributed to students, only $66 \%$ (165) completely filled in questionnaires were received. Amongst the 16 questionnaires distributed amongst the faculty members only 10 questionnaires representing $62.5 \%$ were returned. The researcher hence felt that the views expressed in this article are only the views of the target population.

\section{RESULTS AND DISCUSSION}

The data collected from the questionnaire was tabulated for easy presentation, analysis and presentation. The data was analyzed through the Pearson correlation technique.

Table-4.2: Student Respondents distribution according to Gender, Age and year of study

\begin{tabular}{|l|l|l|l|}
\hline Attributes & Category & Count & Percentage \\
\hline Gender & Male & 115 & $70 \%$ \\
\cline { 2 - 4 } & Female & 50 & $30 \%$ \\
\hline \multirow{5}{*}{ Age } & Total & $\mathbf{1 6 5}$ & $\mathbf{1 0 0 \%}$ \\
\hline \multirow{5}{*}{ Year of study } & $<21$ years & 14 & $8.4 \%$ \\
\cline { 2 - 4 } & $21-25$ years & 105 & $63.63 \%$ \\
\cline { 2 - 4 } & $26-30$ years & 34 & $20.60 \%$ \\
\cline { 2 - 4 } & Above 30 years & 12 & $7.28 \%$ \\
\hline & Total & $\mathbf{1 6 5}$ & $\mathbf{1 0 0 \%}$ \\
\hline & One & 31 & $18.80 \%$ \\
\cline { 2 - 4 } & Two & 73 & $44.24 \%$ \\
\cline { 2 - 4 } & Three & 57 & $34.54 \%$ \\
\cline { 2 - 4 } & Four & 2 & $1.21 \%$ \\
\cline { 2 - 4 } & Five & 2 & $1.21 \%$ \\
\hline \multirow{5}{*}{ Branch of study } & Total & $\mathbf{1 6 5}$ & $\mathbf{1 0 0 \%}$ \\
\cline { 2 - 4 } & Arts & 32 & $19.40 \%$ \\
\cline { 2 - 4 } & Business Administration & 42 & $25.48 \%$ \\
\cline { 2 - 4 } & Education & 56 & $33.92 \%$ \\
\cline { 2 - 4 } & Computer Science and Information Technology & 28 & $16.96 \%$ \\
\cline { 2 - 4 } & Library Sciences & 7 & $4.24 \%$ \\
\hline & Total & $\mathbf{1 6 5}$ & $\mathbf{1 0 0 \%}$ \\
\hline
\end{tabular}

Source: Primary Data

Table 4.2 indicates that out of total 165 student respondents 110 are male respondents and 50 are female respondents. Out of the total students respondents, in the age category majority of them $(63.63 \%)$ belong to the $21-25$ years category, while $20.60 \%$ respondents belong to the $26-30$ years category, while $7.28 \%$ belong to above 30 years category. In the year of study category $44.24 \%$ of the students belong to the second year of their study, while $34.54 \%$ belong to the third year of their study, while $18.80 \%$ respondents belong to the first year of their study. Under the branch of study majority of the respondents are from the education wing, followed by the business administration, arts, computers and the library sciences

Table-4.3: Distribution of respondents by the opinion on the availability of ICT resources

\begin{tabular}{|l|l|l|l|}
\hline ICT resources & Status & Frequency & Percent \\
\hline Computers /PC in classroom & Not Sure & 128 & $73.14 \%$ \\
\cline { 2 - 4 } & Fairly available & 24 & $13.72 \%$ \\
\cline { 2 - 4 } & Available & 23 & $13.14 \%$ \\
\hline \multirow{4}{*}{ Internet and E-mail } & Not Sure & 110 & $62.86 \%$ \\
\cline { 2 - 4 } & Fairly available & 40 & $22.86 \%$ \\
\cline { 2 - 4 } & Available & 25 & $14.28 \%$ \\
\hline \multirow{4}{*}{ Television Set } & Not Sure & 75 & $42.86 \%$ \\
\cline { 2 - 4 } & Fairly available & 66 & $37.72 \%$ \\
\cline { 2 - 4 } & Available & 34 & $24 \%$ \\
\hline Projector & Not Sure & 42 & $35.72 \%$ \\
\cline { 2 - 4 } & Fairly available & 80 & $33.74 \%$ \\
\cline { 2 - 4 } & Available & 53 & $44.78 \%$ \\
\hline Computer laboratory & Not Sure & 55 & $21.48 \%$ \\
\cline { 2 - 4 } & Fairly available & 73 & \\
\cline { 2 - 4 } & Available & 35 & \\
\hline
\end{tabular}

From table 4.3 we can observe that around $128(73.14 \%)$ of the students are not sure that computers are installed in the classroom, while 24 students have accepted it is fairly available, 23 students have agreed it is available. $110(62.86 \%)$ students are not sure that there is internet and email facility in the campus, 40 
Lalitha. B.S., J Adv Educ Philos, Apr, 2021; 5(4): 90-97

students agree that internet facility is available fairly in the campus and 25 students agree that there is internet connectivity in the colleges. $75(42.86 \%)$ students are not sure of presence of television in the campus, whereas 66 students $(37.72 \%)$ agree that television are fairly available, while 34 students (19.42\%) have agreed to television is available. $45.72 \%$ of the students have agreed that projector is fairly available in the campus, while $30.28 \%$ of the students have agreed that projector facility is there in the campus and $24 \%$ have disagreed that there is no projector facility available in the campus. $44.78 \%$ of the students have agreed that computer lab facility is fairly available in the campus, $21.48 \%$ of the students have only agreed that the facility is available in the campus while $33.74 \%$ are not sure about the availability of computer lab facilities in the campus.

\section{Respondent's opinions on the adequacy of ICT resources- \\ One of the major factors affecting the} integration of the ICT is the adequacy of these tools. If the available ICT resources are inadequate then faculties and students may not realize the full potential

Table-4.4: Distribution of respondents by the opinion on the adequacy of ICT resources

\begin{tabular}{|l|l|l|l|}
\hline ICT resources & Status & Frequency & Percent \\
\hline \multirow{3}{*}{ Computers /PC in the classroom } & Inadequate & 115 & $65.70 \%$ \\
\cline { 2 - 4 } & Fairly adequate & 49 & $3.27 \%$ \\
\cline { 2 - 4 } & Adequate & 11 & $7.33 \%$ \\
\hline \multirow{3}{*}{ Internet and E-mail } & Inadequate & 105 & $60 \%$ \\
\cline { 2 - 4 } & Fairly adequate & 50 & $3.33 \%$ \\
\cline { 2 - 4 } & Adequate & 20 & $11.42 \%$ \\
\hline \multirow{3}{*}{ Television Set } & Inadequate & 97 & $55.42 \%$ \\
\cline { 2 - 4 } & Fairly adequate & 60 & $34.28 \%$ \\
\cline { 2 - 4 } & Adequate & 18 & $10.28 \%$ \\
\hline \multirow{3}{*}{ Projector } & Inadequate & 70 & $40 \%$ \\
\cline { 2 - 4 } & Fairly adequate & 80 & $45.71 \%$ \\
\cline { 2 - 4 } & Adequate & 23 & $13.14 \%$ \\
\hline \multirow{3}{*}{ Computer laboratory } & Inadequate & 100 & $57.14 \%$ \\
\cline { 2 - 4 } & Fairly adequate & 45 & $25.71 \%$ \\
\cline { 2 - 4 } & Adequate & 30 & $17.14 \%$ \\
\hline
\end{tabular}

From table 4.4, under the adequacy of computers in the classroom around $65.70 \%$ of the students feel that there inadequacy of system availability in the campus. Only $3.27 \%$ and $7.33 \%$ of the students feel that the facility is fairly adequate and adequate in the classroom. Under the internet and email category, $60 \%$ of the students feel that these facilities are inadequate while $11.42 \%$ and $3.33 \%$ of the students have opined that the facilities are adequate and fairly adequate available in the campus. Under the availability of the television category, $55.42 \%$ of the students expressed that there are inadequate television in the campus, while $34.28 \%$ have felt the availability is fairly adequate and $10.28 \%$ have felt that it is adequately available. Under the projector category, $45.71 \%$ of students that projectors are fairly available in the colleges, while $40 \%$ of them felt the facility are inadequate and $13.14 \%$ felt the adequacy of projectors in the campus. Under the computer laboratory category, $57.14 \%$ felt the lab facilities are inadequate while $25.71 \%$ of the students feel the facilities are fairly adequate and $17.14 \%$ felt the adequacy of computer labs in the campus.

Table-4.5: Distribution of respondents by the opinion on the accessibility of ICT resources

\begin{tabular}{|l|l|l|l|}
\hline ICT resources & Response & Frequency & Percent \\
\hline \multirow{4}{*}{ Library } & Never at all & 42 & $24.27 \%$ \\
\cline { 2 - 4 } & Not sure & 6 & $3.47 \%$ \\
\cline { 2 - 4 } & Sometimes & 106 & $61.27 \%$ \\
\cline { 2 - 4 } & Always & 19 & $10.98 \%$ \\
\hline \multirow{5}{*}{ Computer labs } & Never at all & 12 & $6.89 \%$ \\
\cline { 2 - 4 } & Not sure & 9 & $5.17 \%$ \\
\cline { 2 - 4 } & Sometimes & 102 & $58.6 \%$ \\
\cline { 2 - 4 } & Always & 51 & $29.31 \%$ \\
\hline \multirow{5}{*}{ Internet Kiosk } & Never at all & 73 & $41.95 \%$ \\
\cline { 2 - 4 } & Not sure & 5 & $2.87 \%$ \\
\cline { 2 - 4 } & Sometimes & 50 & $28.73 \%$ \\
\cline { 2 - 4 } & Always & 46 & $10.34 \%$ \\
\cline { 2 - 4 } & Never at all & 67 & $38.50 \%$ \\
\cline { 2 - 4 } & Not sure & 18 & $12.64 \%$ \\
\cline { 2 - 4 } & Sometimes & 67 & \\
\cline { 2 - 4 } & Always & 22 & \\
\hline
\end{tabular}


From table 4.5 students opined that the library facility for usage of ICT resources is available to the students sometimes (61.27\%) only, $24.27 \%$ students expressed that they have never used such facility at all in the campus, $10.98 \%$ students said that they have always used the ICT facilities in the library. On the usage of computer labs category, $58.6 \%$ students have expressed that they have used the facility sometimes, $29.31 \%$ of the students have agreed that they have used the facility always, $6.89 \%$ students have never used such a facility, $5.17 \%$ are not sure of such a facility in the campus itself. Under the usage of ICT facility in the classroom $41.95 \%$ of the students have never used such a service, $28.73 \%$ have used the feature sometimes in the campus, $26.28 \%$ students are always using such a resource in the campus, $2.87 \%$ students are not sure of such a facility at all. Under the availability of the internet kiosk in the campus $38.50 \%$ have expressed that the facility is never available at all or available only sometimes in the campus. Only $12.64 \%$ have expressed that internet kiosk facility are available always, while $10.34 \%$ are not sure of the facility availability in the campus.

Table-4.6: Challenges faced by students in accessing the internet

\begin{tabular}{|l|l|}
\hline Challenges affecting usage of ICT resources & Percentage of problems \\
\hline Load Shedding & $4 \%$ \\
\hline Poor management & $6 \%$ \\
\hline Unreliable internet facility & $7 \%$ \\
\hline Limited time to access the computer lab & $10 \%$ \\
\hline Financial constraints & $13 \%$ \\
\hline Limited ICT resources & $60 \%$ \\
\hline
\end{tabular}

Source: Primary Data

From the above table we can observe that limited ICT resources are the major constraint for the growth of learning in the students $(60 \%)$, this is followed by the financial constraints. These affiliated colleges are facing a financial crunch and have not been able to provide the best of the ICT resources to the students. Added to these woes one more major problem faced by the students are the limited hours of access towards usage of these resources

Table-4.7: Distribution of respondents by the opinion on the student's skills of usage of ICT tools

\begin{tabular}{|c|c|c|c|}
\hline ICT resources & Level of skill usage & Frequency & Percent \\
\hline \multirow{5}{*}{ MS Word } & Very poor & 10 & $5.71 \%$ \\
\hline & Poor & 11 & $6.28 \%$ \\
\hline & Fair & 40 & $22.85 \%$ \\
\hline & Good & 72 & $41.14 \%$ \\
\hline & Very good & 42 & $24 \%$ \\
\hline \multirow{5}{*}{ MS Excel } & Very poor & 14 & $8 \%$ \\
\hline & Poor & 13 & $7.42 \%$ \\
\hline & Fair & 60 & $34.28 \%$ \\
\hline & Good & 62 & $35.42 \%$ \\
\hline & Very good & 26 & $14.85 \%$ \\
\hline \multirow{5}{*}{ MS Power Point } & Very poor & 21 & $12 \%$ \\
\hline & Poor & 22 & $12.57 \%$ \\
\hline & Fair & 65 & $37.14 \%$ \\
\hline & Good & 42 & $24 \%$ \\
\hline & Very good & 25 & $14.28 \%$ \\
\hline \multirow{5}{*}{ Projectors } & Very poor & 32 & $18.28 \%$ \\
\hline & Poor & 35 & $20 \%$ \\
\hline & Fair & 45 & $25.71 \%$ \\
\hline & Good & 42 & $24 \%$ \\
\hline & Very good & 21 & $12 \%$ \\
\hline \multirow{5}{*}{ Internet and E-mail } & Very poor & 10 & $5.71 \%$ \\
\hline & Poor & 13 & $7.42 \%$ \\
\hline & Fair & 40 & $22.85 \%$ \\
\hline & Good & 49 & $28 \%$ \\
\hline & Very good & 63 & $36 \%$ \\
\hline
\end{tabular}


Lalitha. B.S., J Adv Educ Philos, Apr, 2021; 5(4): 90-97

From Table 4.7, from Ms-Word category $41.14 \%$ have agreed that they are very good on usage of the Ms-Word, $24 \%$ of the students fall under the very good category, $22.85 \%$ feel they can complete the work in a fair manner using the Ms-Word, while $6.28 \%$ and $5.71 \%$ students fall under the poor and very poor category for usage of the word document. Under the MS-Excel category $35.42 \%$ are good in the usage of MS-Excel, $34.28 \%$ have a fair exposure towards usage of MS-Excel, $14.85 \%$ are very good at usage of excel while $8 \%$ and $7.42 \%$ students have very poor and poor exposure to usage of excel in the campus. Under the projector usage category around $24 \%$ of students are used to usage of projectors in the classroom, $25.71 \%$ have agreed that they have a fair knowledge of the same, $12 \%$ of the students have very good exposure in usage of projectors, while $20 \%$ and $18.28 \%$ have very poor exposure in the usage of projectors. Under the internet and e-mail category, $36 \%$ and $28 \%$ of the students have good experience on usage of mail facility, $22.85 \%$ have a fair knowledge on usage of internet while $7.42 \%$ and $5.71 \%$ have very poor awareness on the usage of internet and email in the campus.

Hypothesis 1

Table-4.8: Table showing the correlation between availability of ICT resources and student learning

\begin{tabular}{|c|c|c|c|}
\hline & & Students learning & Availability of ICT resources \\
\hline \multirow{3}{*}{ Students learning } & Pearson correlation & 1 & .587 \\
\hline & Sig(2-tailed) & & .000 \\
\hline & $\mathrm{N}$ & 175 & 175 \\
\hline \multirow[t]{3}{*}{ Availability of ICT resources } & Pearson correlation & .587 & 1 \\
\hline & Sig(2-tailed) & .000 & \\
\hline & $\mathrm{N}$ & 175 & 175 \\
\hline
\end{tabular}

The analysis indicated that it shows a positive linear relationship between availability of ICT resources and students learning as indicated by the correlation test of 0.587 . The p-value (.000) is less than the value at $5 \%$ level of significance which indicates that the results are statistically significant. This indicates that there is a positive relationship between availability of ICT resources and students learning. Alternative hypothesis is accepted.

Hypothesis 2

Table-4.9: Table showing the correlation between accessibility of ICT resources and student learning

\begin{tabular}{|l|l|l|l|}
\hline \multicolumn{2}{|c|}{} & Students learning & Accessibility of ICT resources \\
\hline \multirow{3}{*}{ Students learning } & Pearson correlation & 1 & .549 \\
\cline { 2 - 4 } & Sig(2-tailed) & & .000 \\
\cline { 2 - 4 } & $\mathrm{N}$ & 175 & 175 \\
\hline $\begin{array}{l}\text { Accessibility of ICT } \\
\text { resources }\end{array}$ & Pearson correlation & .549 & 1 \\
\cline { 2 - 4 } & Sig(2-tailed) & .000 & 175 \\
\cline { 2 - 4 } & $\mathrm{N}$ & 175 & \\
\hline
\end{tabular}

The analysis indicated that it shows a positive linear relationship between availability of ICT resources and students learning as indicated by the correlation test of 0.549 . The p-value (.000) is less than the value at $5 \%$ level of significance which indicates that the results are statistically significant. This indicates that there is a positive relationship between availability of ICT resources and students learning. Alternative hypothesis is accepted. It can be understood from the above table that the accessibility to ICT may improve student learning.

Hypothesis 3

Table-4.10: Table showing the correlation between user ability of ICT resources and student learning

\begin{tabular}{|l|l|l|l|}
\hline \multicolumn{2}{|l|}{} & Students learning & User ability of ICT resources \\
\hline \multirow{3}{*}{ Students learning } & Pearson correlation & 1 & .715 \\
\cline { 2 - 4 } & Sig(2-tailed) & & .000 \\
\cline { 2 - 4 } & $\mathrm{N}$ & 175 & 175 \\
\hline $\begin{array}{l}\text { Accessibility of ICT } \\
\text { resources }\end{array}$ & Pearson correlation & .715 & 1 \\
\cline { 2 - 4 } & Sig(2-tailed) & .000 & 175 \\
\cline { 2 - 4 } & $\mathrm{N}$ & 175 & \\
\hline
\end{tabular}

The analysis indicated that it shows a positive linear relationship between user ability of ICT resources and students learning as indicated by the correlation test of 0.715 . The p-value (.000) is less than the value at $5 \%$ level of significance which indicates that the results are statistically significant. This indicates that there is a positive relationship between availability of ICT 
resources and students learning. Alternative hypothesis is accepted.

\section{FINDINGS}

1. Majority of the students have agreed that the availability of ICT resources is limited. Hence more number of systems must be installed. Further these systems usage is confined mainly to the computer labs and many times the internet connection is hardly available. So the availability of the ICT resources can enhance the learning of the students. This reduces the dependence of the students on the teachers and try to learn new things on their own

2. Students have to use excel, power point, word, internet and email facilities as a part of their curriculum and completion of projects. This enhances their overall thinking capacity, decision making abilities when compared to the traditional mode of education.

3. Inadequacy of ICT facilities turns into lack of skills which results in lack of confidence in utilizing the ICT tools amongst the students

4. Lack of resources has compelled the colleges to allot the computer labs to students for minimal hours in a week. Hence preparation of timetable for the usage of the systems has become essential.

5. Accessibility of the internet is very much poor in lecture halls, libraries. Limited time to access the computer lab, poor internet connectivity, and power fluctuation has affected student's access to ICT. Hence we can say that ICT learning is not completely implemented in the colleges.

\section{SUGGESTIONS}

1. Affiliated colleges need to invest more in computers and related technology as means of solving accessibility problem. This provides more scope for practice and utilization

2. Better internet connectivity must be maintained and liberalized for student usage

3. Training in ICT must not be restricted to MS Office but extended to other programs and packages as per the current needs of the industry.

\section{CONCLUSION}

ICT has revolutionized almost all the operations across the world. It has created platforms and opportunities that have aided to the acquisition of knowledge. Smart phones and laptops are critical in the access of ICT facilities and to search information on the internet. ICT is used to facilitate discussions and feedback from teachers, seniors and colleagues. This type of interaction helps to improve their study and research skills. The study revealed that majority of the students use ICT for their students and hence full support is required to improve their academic performance. There is no doubt that ICT has enhanced the academic performance of the students and it has a positive effect on the student learning. But it has brought with it some negative aspects also. Excessive usage can hamper the student learning process and hence blocking of illicit websites for students are given considerations by teachers, parents and cafe operators. Hence students must be advised against the misuse of ICT.

\section{REFERENCE}

1. Ullah, M. A., Alam, M. M., Shan-A-Alahi, A., Rahman, M. M., Masum, A. K. M., \& Akter, N. Impact of ICT on Students 'Academic Performance: Applying Association Rule Mining and Structured Equation Modeling.

2. Chakraborty, D., Dhara, S. K., \& Santra, A. (2018). Effectiveness of ICT in Strengthening the Process of Higher Education System in India.

3. Feltovich, P. J., Coulson, R. L., Spiro, R. J., \& Dawson-Saunders, B. K. (1992). Knowledge application and transfer for complex tasks in illstructured domains: Implications for instruction and testing in biomedicine. In Advanced models of cognition for medical training and practice (pp. 213-244). Springer, Berlin, Heidelberg.

4. Al-Hariri, M. T., \& Al-Hattami, A. A. (2017). Impact of students' use of technology on their learning achievements in physiology courses at the University of Dammam. Journal of Taibah University Medical Sciences, 12(1), 82-85.

5. Mwendwa, N. K. (2009). Availability of Resource Materials and Facilities for ICT Integration in the Public Primary School Curriculum in Kitui County, Kenya.

6. Basri, W. S., Alandejani, J. A., \& Almadani, F. M. (2018). ICT adoption impact on students' academic performance: Evidence from Saudi universities. Education Research International, 2018.

7. Nurjanah, S., Santoso, H. B., \& Hasibuan, Z. A. (2017). An ICT Adoption Framework for Education: A Case Study in Public Secondary School of Indonesia. In Journal of Physics: Conference Series (Vol. 801, No. 1, p. 012029). IOP Publishing.

Websites used:

https://ugcnetpaper1.com/digital-initiative-in-highereducation/

https://www.orfonline.org/expert-speak/increasingenrolment-in-higher-education-a-quantitative-andqualitative-challenge-55883/ https://mhrd.gov.in/sites/upload_files/mhrd/files/statisti cs-new/AISHE2015-16.pdf https://ictcurriculum.gov.in/mod/page/view.php?id=310 